\title{
Arylation Using Sulfonamides: Phenylacetamide Synthesis through Tandem Acylation-Smiles Rearrangement
}

DOI:

10.1021/acs.orglett.9b03429

\section{Document Version}

Accepted author manuscript

Link to publication record in Manchester Research Explorer

\section{Citation for published version (APA):}

Barlow, H. L., Rabet, P. T. G., Durie, A., Evans, T., \& Greaney, M. F. (2019). Arylation Using Sulfonamides:

Phenylacetamide Synthesis through Tandem Acylation-Smiles Rearrangement. Organic Letters, 9033-9035. https://doi.org/10.1021/acs.orglett.9b03429

\section{Published in:}

Organic Letters

\section{Citing this paper}

Please note that where the full-text provided on Manchester Research Explorer is the Author Accepted Manuscript or Proof version this may differ from the final Published version. If citing, it is advised that you check and use the publisher's definitive version.

\section{General rights}

Copyright and moral rights for the publications made accessible in the Research Explorer are retained by the authors and/or other copyright owners and it is a condition of accessing publications that users recognise and abide by the legal requirements associated with these rights.

\section{Takedown policy}

If you believe that this document breaches copyright please refer to the University of Manchester's Takedown Procedures [http://man.ac.uk/04Y6Bo] or contact uml.scholarlycommunications@manchester.ac.uk providing relevant details, so we can investigate your claim.

\section{OPEN ACCESS}




\title{
Arylation using sulfonamides: Phenylacetamide synthesis through tandem acylation-Smiles rearrangement
}

\author{
Helen L. Barlow, Pauline T. G. Rabet, Alastair Durie, Tim Evans, Michael F. Greaney* \\ School of Chemistry, University of Manchester, Oxford Road, Manchester, UK, M13 9PL, UK
}

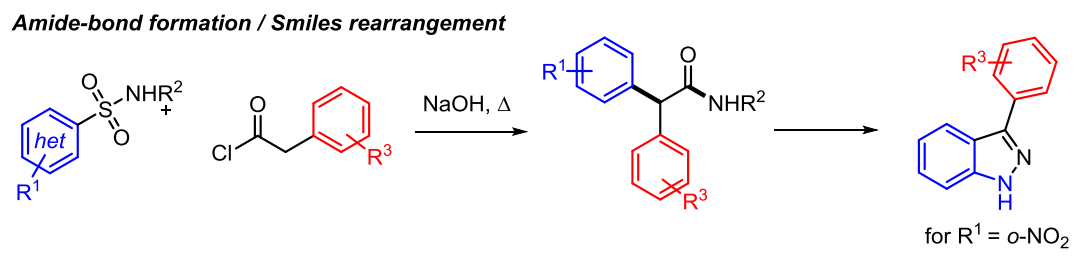

\begin{abstract}
A range or electron-poor and heterocyclic sulfonamides react with phenylacetyl chlorides to produce benzhydryl derivatives in a single step. The reaction proceeds via tandem amide bond formation - Dohmori-Smiles rearrangement under simple conditions of aqueous base. In the case of o-nosylamides further reaction takes place at the nitro
\end{abstract} group to yield indazoles.

Aryl and heteroaryl structures are fundamental to natural products and man-made molecules, and are frequently synthesized using stoichiometric organometallics and precious transition metal catalysts. These methods, while effective and hugely influential, are costly and environmentally unsustainable, making metal-free arylation methods ${ }^{1}$ a key objective for future strategies in synthetic chemistry. We are interested in harnessing simple aryl sulfonamides as metal-free arylating agents in this regard, through the process set out in Scheme 1. The nitrogen atom acts as a nucleophilic trap for an electrophilic coupling partner, a benzyne in this example, generating an incipient carbanion (3) that triggers a 1,5-desulfonylative Smiles rearrangement. ${ }^{2,3,4}$ Overall, the process repositions a cheap and readily available building block as both an arylating and aminating agent, critical transformations in the pharmaceutical industry, whilst proceeding without recourse to metal reagents.

We have previously shown that sulfonamides can react with sp-electrophiles for the synthesis of biaryl and enaminoate products, ${ }^{5}$ and were interested in extending the chemistry to $\mathrm{sp}^{2}$ components. Trapping a ketene, $\mathbf{7}$, for example, with a sulfonamide $\mathbf{1}$, would generate an enolate 8 that could rearrange via Smiles reaction to afford phenylacetamide derivatives $\mathbf{9}$. This process would use sulfonamides to install aryl groups at $\mathrm{sp}^{3}$ centres, producing phenylacetamides, a fundamental pharmacophore in medicinal chemistry. The Smiles rearrangement of acylsulfonamide enolates akin to $\mathbf{8}$ has precedent in seminal studies from Dohmori and co-workers in the 1950s, representing the earliest examples of carbon nucleophiles participating in Smiles processes. ${ }^{6}$

Our previous work indicates that electron poor sulfonamides are required for anionic desulfonylative Smiles processes, in line with literature precedent of an $S_{N} A r-t y p e$ mechanism that proceeds through a Meisenheimer intermediate (e.g. 4 in Scheme 1). ${ }^{7}$

Scheme 1. Proposed ketene Smiles rearrangement

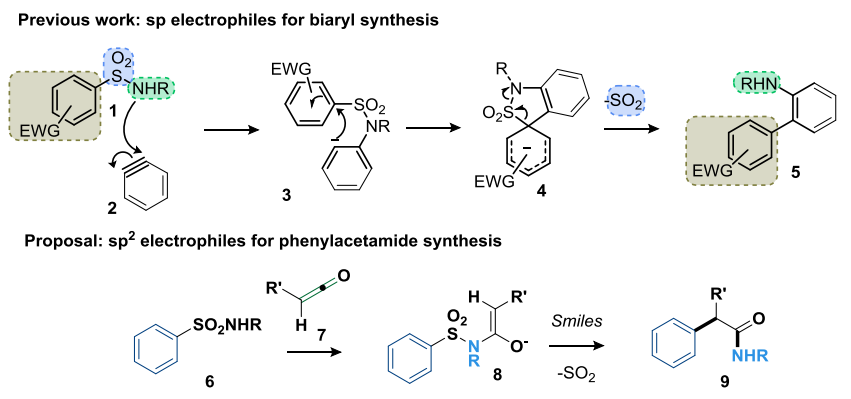

Accordingly, we began our studies using $p$-nosylamide 1a, and screened reaction with excess phenylacetyl (1oa) and propionyl chloride (1ob) under ketene-forming conditions in terms of solvent and temperature (Table 1). Unfortunately, no Smiles reaction could be observed, with the simple acylated product being identified as the main product in each case (entries 1-7). A further trial with the diketene acetone adduct at $120{ }^{\circ} \mathrm{C}$, to generate acylketene in situ, likewise yielded the acylated sulfonamide only. It appeared that the 1,5-desulfonylative Smiles reaction, in contrast to some 1,4 processes on related enolate systems, ${ }^{8}$ requires more basic conditions to proceed. This proved to be the case, as a survey of simple inorganic bases identified aq $\mathrm{NaOH}$ as enabling the two step procedure (entry 8). Using aqueous THF as solvent, $p$ nosylsulfonamide reacted with phenylacetyl chloride at $80^{\circ} \mathrm{C}$ to give the Smiles product $9 \mathrm{a}$ in a very good yield. 
Table 1. Reaction optimization

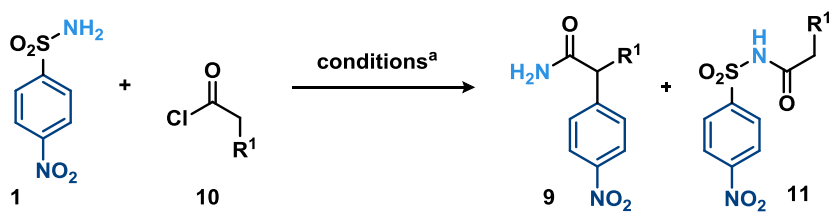

\begin{tabular}{|c|c|c|c|c|c|}
\hline entry & $\mathrm{R}^{1}$ & base & solvent & $\mathrm{T}\left({ }^{\circ} \mathrm{C}\right)$ & product \\
\hline 1 & $\mathrm{Ph}$ & $\begin{array}{c}{ }^{i} \mathrm{Pr}_{2} \mathrm{NEt} \\
(\text { 2.o) }\end{array}$ & DCM & r.t. & 11 \\
\hline 2 & $\mathrm{Ph}$ & $\begin{array}{c}\text { proton } \\
\text { sponge } \\
(1.1)\end{array}$ & DCM & 40 & 11 \\
\hline 3 & $\mathrm{Ph}$ & $\begin{array}{c}\text { proton } \\
\text { sponge } \\
(1.1)\end{array}$ & DCM & r.t. & 11 \\
\hline 4 & $\mathrm{Ph}$ & $\begin{array}{c}{ }^{i} \mathrm{Pr}_{2} \mathrm{NEt} \\
(\text { 2.o) }\end{array}$ & THF & 70 & 11 \\
\hline 5 & $\mathrm{CH}_{3}$ & $\begin{array}{c}{ }^{i} \mathrm{Pr}_{2} \mathrm{NEt} \\
(2.0)\end{array}$ & THF & 100 & 11 \\
\hline 6 & $\mathrm{CH}_{3}$ & $\begin{array}{c}{ }^{i} \mathrm{Pr}_{2} \mathrm{NEt} \\
(\mathbf{2 . 0})\end{array}$ & toluene & 100 & 11 \\
\hline 7 & $\mathrm{CH}_{3}$ & $\begin{array}{c}\text { proton } \\
\text { sponge } \\
(1.1)\end{array}$ & THF & 100 & 11 \\
\hline $8^{\mathrm{b}}$ & $\mathrm{Ph}$ & $\begin{array}{c}\mathrm{NaOH} \\
\text { (aq) }\end{array}$ & THF & 80 & 9a $(87 \%)^{c}$ \\
\hline
\end{tabular}

${ }^{\text {a }}$ Reaction conditions: 1 ( 1 equiv) in solvent at $\mathrm{o}{ }^{\circ} \mathrm{C}$, then the base was added, followed by 10 (1 equiv), stirred at $\mathrm{T}{ }^{\circ} \mathrm{C}$ for $16 \mathrm{~h}^{\mathrm{b}} 5$ equiv of $10,1 \mathrm{~h}^{\mathrm{c}}$ Isolated yield.

With reaction conditions in hand we examined substrate scope in terms of aryl halide and sulfonamide component (Scheme 2). The reaction was successful for a variety of phenacetyl chlorides, affording the benzhydryl primary amides 9a - 9o in generally good yield. The reaction could be demonstrated on a $1 \mathrm{mmol}$ scale for the synthesis of 9a, proceeding in an excellent $89 \%$ yield. Some restrictions were noted in terms of substitution at the enolic position of the acyl component, with di-substitution at this position shutting down the Smiles process. Turning to the sulfonamide partner, the reaction tolerated $\mathrm{N}$ substitution (e.g. 9h and 9i) without problem, but not $\mathrm{N}, \mathrm{N}$-disubstitution. Electron poor $p$-nosylamides were generally productive, and we were pleased to see that heterocyclic sulfonamides such as pyrimidyl (9m), pyrimidyl (9n) and benzothiazoyl (9o) underwent successful reaction. Arylation of $\mathrm{sp}^{3}$ centres with these valuable heteroarenes moieties under simple metal-free conditions is a particular strength of the approach, as it represents a challenging transformation for contemporary transitionmetal catalyzed methods.

Screening o-nosylamide $1 \mathrm{e}$ in the reaction led to the unexpected formation of 3-phenyl- $1 \mathrm{H}$-indazole $12 \mathrm{a}$ in $54 \%$ yield (Scheme 3A). The reaction appears general for phenylacetyl chlorides, with the electron rich and electron poor substrates giving the indazoles $\mathbf{1 2 a}$ - $12 \mathbf{f}$ in moderate yields.

Scheme 2. Acyl chloride substrate scope $\mathrm{e}^{\mathrm{a}, \mathrm{b}}$

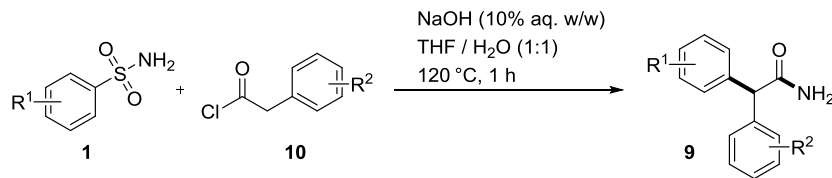

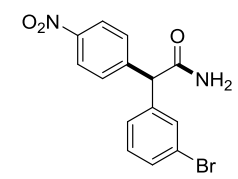

$9 b, 81 \%$
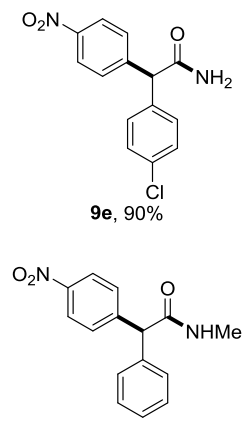

9h, $83 \%$

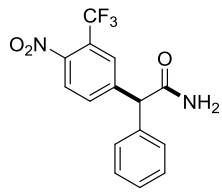

$9 k, 87 \%$

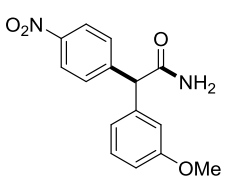

$9 c, 86 \%$

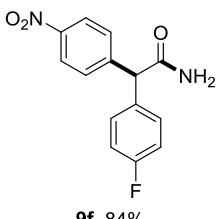

9i, $91 \%$

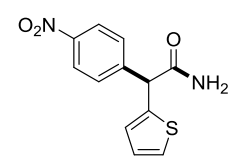

91, $67 \%$

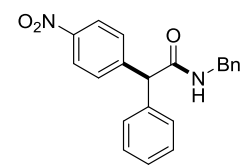

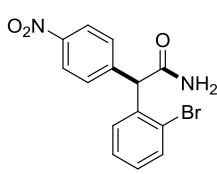

9d, $70 \%$
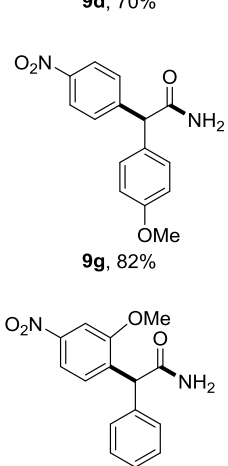

9j, $74 \%$

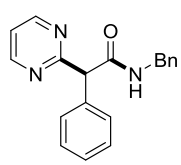

$9 \mathrm{~m}, 72 \%$

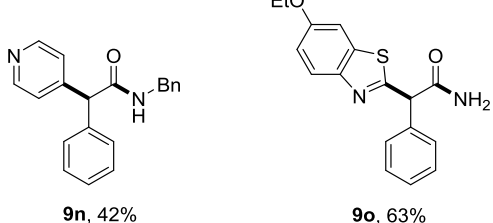

${ }^{\text {a }}$ Reaction conditions: 1 ( 1 equiv) in THF at $\mathrm{o}^{\circ} \mathrm{C}$. Dropwise addition of aq $\mathrm{NaOH}$ followed by 10 ( 5 equiv), then heat to $120^{\circ} \mathrm{C}$ in sealed vial for $1 \mathrm{hr}$.

Assembly of this important heterocycle from sulfonamides, in a single step, has not previously been reported and clearly involves a significant degree of bond reorganization. There is, however, some limited precedent in work from Dohmori and Sundberg who observed indazole synthesis from Smiles products via cinnoline $\mathrm{N}$ oxides. ${ }^{6,9010}$ A feasible pathway is shown in Scheme $3 \mathrm{~B}$, whereby the sulfonamide undergoes acylative Smiles rearrangement to afford $\mathbf{9 p}$, which can then undergo intramolecular N-N bond formation to form the cinnoline $\mathrm{N}$ Oxide 13. From here, basic hydrolysis of the cinnoline amide group and dehydration would form the diazonium 
intermediate 14, and intramolecular amination of enolates analogous to $\mathbf{1 4}$ is a well-described method for synthesizing indazoles." A final decarboxylation gives the product 12.

Scheme 3. $1 \mathrm{H}$-Indazole synthesis ${ }^{\mathrm{a}, \mathrm{b}}$

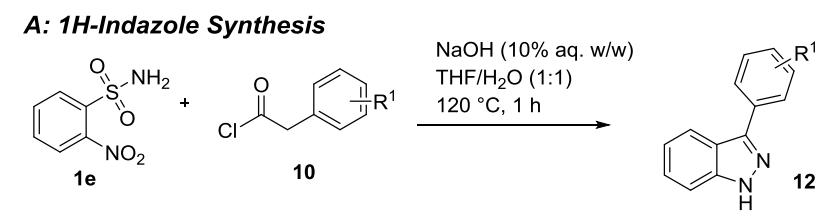

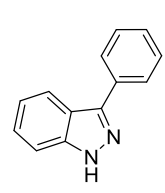

$12 a, 54 \%$

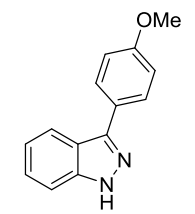

12d, $53 \%$

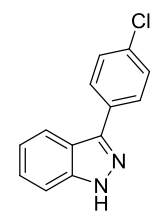

12b, $52 \%$

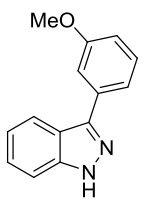

$12 e, 61 \%$

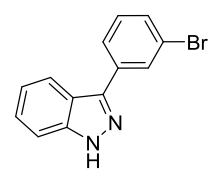

$12 c, 66 \%$

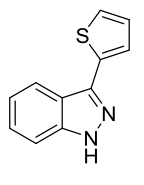

$12 f, 71 \%$

\section{B: Proposed mechanism}
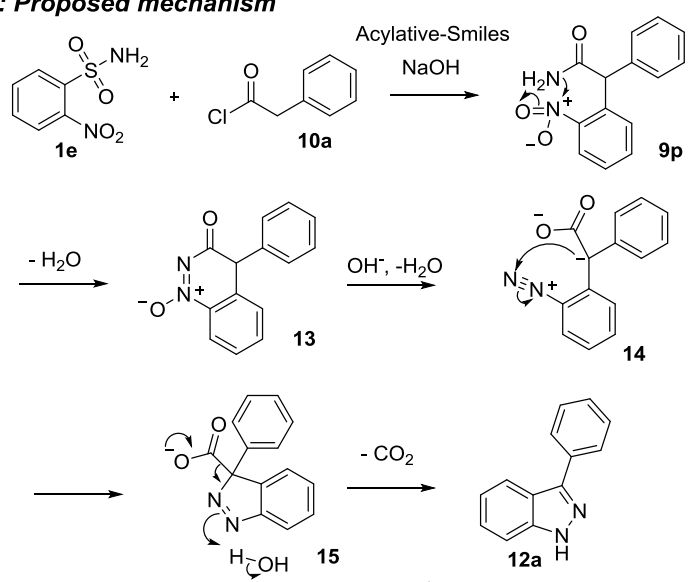

${ }^{\mathrm{a}}$ General conditions as Scheme 2. ${ }^{\mathrm{b}}$ Isolated yields.

To conclude, we have described a new application of sulfonamides that captures their amphiphilic character as electrophilic arylating and nucleophilic aminating agents. The transformation is based on classical observations from Dohmori and co-workers on the facility of desulfonylative Smiles processes to mimic enolate arylation chemistry. In contrast to conventional enolate arylations, however, the process requires no metal catalysts and proceeds under very simple conditions. In the case of onosylamides, a 3-aryl-1H-indazole synthesis has been developed that involves substantial changes in bond connectivity to create an important heteroarene moiety from cheap and readily available starting materials.

\section{ASSOCIATED CONTENT}

\section{Supporting Information}

Experimental procedures and characterization data for all new compounds are available in the Supporting Information. This material is available free of charge via the Internet at http://pubs.acs.org.

\section{AUTHOR INFORMATION}

\section{Corresponding Author}

*Michael.greaney@manchester.ac.uk

\section{Author Contributions}

The manuscript was written through contributions of all authors. / All authors have given approval to the final version of the manuscript.

\section{ACKNOWLEDGMENT}

We thank the EPSRC for funding.

\section{REFERENCES}

${ }^{1}$ Sun, C.-L.; Shi, Z.-J. Chem. Rev. 2014, 114, 9219.

${ }^{2}$ Reviews: a) Holden, C. M.; Greaney, M. F. Chem. Eur. J. 2017, 23, 8992-90o8. b) Henderson, A. R. P.; Kosowan, J. R.; Wood, T. E. Can. J. Chem. 2017, 95, 483.

3 Recent desulfonylative Smiles examples: a) Whalley, D. M.; Duong, H. A.; Greaney, M. F. Chem. Eur. J. 2019, 25, 1927; b) Rashid, S. O.; Almadhhi, S. S.; Berrisford, D. J.; Raftery, J.; VitoricaYrezabal, I.; Whitehead, G.; Quayle, P. Tetrahedron, 2019, 75, 2413; c) Bujok, R.; Makosza, M. Synthesis, 2019, 51, 3109; d) Monos, T. M.; McAtee, R. C.; Stephenson, C. R. J. Science, 2018, 361, 1369; e) Coulibali, S.; Godou, T.; Canesi, S. Org. Lett. 2016, 18, 4348; f) Crossley, S. W.; Martinez, R. M.; Guevara-Zuluaga, S.; Shenvi, R. A. Org. Lett. 2o16, 18, 2620; g) Douglas, J. J.; Albright, H.; Sevrin, M. J.; Cole, K. P.; Stephenson, C. R. J. Angew. Chem. Int. Ed. 2015, 54, 14898; h) Fuentes, N.; Kong, W.; FernandezSanchez, L.; Merino, E.; Nevado, C. J. Am. Chem. Soc. 2015, 137, 964; i) Kong, W.; Fuentes, N.; Garcia-Dominguez, A.; Merino, E.; Nevado, C. Angew. Chem. Int. Ed. 2015, 54, 2487.

${ }^{4}$ Recent Smiles examples: a) Chang, X.; Zhang, Q.; Guo, C. Org. Lett. 2019, 21, 4915; b) Li, J.; Liu, Z.; Wu, S.; Chen, Y. Org. Lett. 2019, 21, 2077; c) Faderl, C.; Budde, S.; Kachkovskyi, G.; Rackl, D.; Reiser, O. J. Org. Chem. 2018, 83, 12192; d) Costil, R.; Lefebvre, Q.; Clayden, J. Angew. Chem. Int. Ed. 2017, 56, 14602; e) Wang, S.-F.; Cao, X.-P.; Li, Y. Angew. Chem. Int. Ed. 2017, 56, 13809; f) Costil, R.; Dale, H. J. A.; Fey, N.; Whitcombe, G.; Matlock, J. V.; Clayden, J. Angew. Chem. Int. Ed. 2017, 56, 12533; g) Janssen-Mueller, D.; Singha, S.; Lied, F.; Gottschalk, K.; Glorius, F. Angew. Chem. Int. Ed. 2017, 56, 6276; h) Bhojgude, S. S.; Roy, T.; Gonnade, R. G.; Biju, A. T. Org. Lett. 2016, 18, 5424.

${ }^{5}$ a) Holden, C. A.; Sohel, S. M. A.; Greaney, M. F. Angew. Chem. Int. Ed. 2016, 55, 2450. b) Teskey, C. J.; Sohel, S. M. A.; Bunting, D. L.; Modha, S. G. Angew. Chem. Int. Ed. 2017, 56, 5263.

6 a) Naito, T.; Dohmori, R.; Nagase, O. Yakugaku Zasshi 1954, 74, 593. b) Naito, T.; Dohmori, R.; Sano, M. Yakugaku Zasshi 1954, 74 , 596. See ref $2 \mathrm{~b}$ for further references on the Dohmori-Smiles rearrangement.

7 For a recent discussion of concerted $\mathrm{S}_{\mathrm{N}} \mathrm{Ar}$ reactions, see: Rohrbach, S.; Smith, A. J.; Pang, J. H.; Poole, D. L.; Tuttle, T.; 
Chiba, S.; Murphy, J. A. Angew. Chem. Int. Ed. 2019, Early view, OI: 10.1002/anie.201902216.

${ }^{8}$ Wilson, M. W.; Ault-Justus, S. E.; Hodges, J. C.; Rubin, J. R. Tetrahedron, 1999, 55, 1647.

${ }^{9}$ Loudon, J. D.; Tennant, G. Quart. Rev. (London), 1964, 18, 389.
${ }^{10}$ Sundberg, R. J.; Blackburn, D. E. J. Org. Chem. 1969, 34, 2799.

${ }^{11}$ Yoshida, T.; Matsuura, N.; Yamamoto, K.; Doi, M.; Shimada, K,; Morie, T.; Kato, S. Heterocycles 1996, 43, 2701. 